\title{
The Viability of Mobile Services (SMS and Cell Broadcast) in Emergency Management Solutions: An Exploratory Study
}

\author{
https://doi.org/10.3991/ijim.v12i1.7677 \\ Mahmoud Al-dalahmeh $\left({ }^{\bowtie}\right)$ \\ The University of Jordan, Amman, Jordan \\ m. aldalahmeh@ju.edu.jo \\ Ons Al-Shamaileh, Anas Aloudat \\ American University in the Emirates, Dubai, UAE \\ Bader Obeidat \\ The University of Jordan, Amman, Jordan
}

\begin{abstract}
Utilizing mobile devices for emergency management has gained much interest from governments in the past few years. This interest is mainly due to the high penetration rate of these devices among people and wellestablished, nation-wide coverage of mobile telecommunications networks in many countries around the world; making these devices a feasible means to send alerts or warnings message using short message services (SMS) or warnings for a specific geographic area (cell broadcast services (CBS)) in case of an emergency. As there are quite a number of barriers for investing in and establishing dedicated emergency management solutions in the developing countries, developing emergency solutions by the government of a developing country using its existing mobile telecommunications networks is argued to be feasible and viable. Nevertheless, a better understanding of the deployment of such mobile emergency solutions in context of developing countries is still in its genesis. In particular, the fit between the mobile phone platform and emergency management, delivery models of emergency alerts and warnings through mobile devices, the role of the private telecommunications providers and nongovernment organizations in such solutions, and the non-technical requirements of mobile government emergency solutions are all still not well articulated. A qualitative research approach was carried out to explore these matters of interest. Leximancer software tool and content analysis were used to extract themes of this study. The findings confirm mobile phones as a convenient approach for a developing country to develop its national emergency solution, but a set of requirements toward such development is still critically needed to be met.
\end{abstract}

Keywords-Mobile, Government, Developing Country, Emergency Management, Warning System, Public Safety, Regulatory Framework, Requirement, SMS, CBS 


\section{Introduction}

Mobile emergency services have become an integral part in emergency management strategies in several countries around the world [4]. In general, handheld devices emerged as an important platform in national emergency systems due to their wide spread use among people. Mobile-based emergency solutions are mainly used for two purposes: to find the almost exact geographic location of a person's mobile who is in a distress, and to disseminate updates, alerts, or warning messages to people who are in the vicinity of a threatened area [5]. A mobile phone in case of an large-scale emergency can be used as a channel that permits a government to communicate with citizens and effectively deliver relevant information before, during, or after an emergency, almost instantly and regardless of the time and location of the recipient [6].

Despite the value mobile phones promise to offer in emergency management; a number of barriers do actually hinder their use. Some of these barriers are related to the technical limitations of the telecommunications networks where most of carrier networks cannot provide high accuracy to pinpoint the exact geographic location of a person in need. This is quite true in rural areas [8,33]. Other barriers are associated with social perceptions and public concerns regarding government's potential exploitation of these devices for monitoring and surveillance [4, 27, 23]. Another set of barriers can be linked to economic reasons where emergency management solutions do usually require heavy investments in infrastructure and technology [29, 36].

The importance of this study stems of the fact that it sheds the light on the viability of exploiting mobile devices in national emergency management solutions in developing countries; where most of these countries cannot truly afford investing or establishing dedicated and sophisticated solutions within its national emergency solutions.

Jordan was selected as a case of this research investigation. This selection was made based on three reasons: Jordan well served the purposes of both convenient and purposive sampling where it was convenient for the researchers to secure the intended participants of interest from the country and, at the same time, guarantee the participation of the most appropriate subjects who suit the purpose of this study $[25,11]$. Secondly, Jordan is considered a good example of a developing country with limited resources and moderate economic capabilities [35]. The third reason is the fact that no mobile-based emergency solutions currently exist in Jordan, which fits this research in understanding the feasibility of mobile devices in a developing country's emergency management planning. The rest of the paper is structured as follows: Section Two present gab in the research and the importance of this study. Section Three précis a background about the concepts of emergency, emergency management, Short Mesage Service, Cell Broad Cast Services and literature related to existing mobile phone technologies that can be potentially used in emergency management. Section Four present of a unique comparison of the current state of mobile phone systems in a number of developing Countries. In Section Five a description is given about the qualitative research methodology used. The findings of this research and the analysis are discussed in Section Six. Section Seven confess the presence of some limitations in Mobile Service in emergency management. Finally,Section Eight concludes this article. 


\section{The Call for This Research}

To a huge degree, research into public assistance of mobile telephone services i.e. government to citizen for emergency purposes has been restricted, technical viability studies worldwide, particularly in developing countries, about these electronic services has been limited, as well as there is a stamped scarcity in theoretical and empirical research that particularly addresses the issues surrounding the usage of Mobile Services for emergency management. Accordingly, there is a clear gap in the current body of knowledge coordinated towards establishing the suitability of mobile telephone services in emergency management. The contribution of this study can be outlined as the following: the research's exact enlightenment for the need to mobile telephone services in emergency management, its presentation of an important comparison among currently available technologies within mobile phone services used in emergency (SMS and CBS) in a number of developing countries ( table 2), Coduct a semi-structured interviews with expert people, national and international experience, in the National Security, E-government, Mobile Telecommunications and Emergency Management, extract valuble themes from these interviews, and its listing of key requirements of relevant and appropriate use of the above mentioned services, which will lead to their sure success in developing countries including Jordan.

\section{Background}

Several definitions for emergency are presented in emergency management literature. Most of these definitions focus on measuring the magnitude of negative impacts of a specific incident on lives and properties [12]. Other definitions set the level of impact, including number of casualties, injured people, or the magnitude of destruction in infrastructures and properties in order to differentiate between emergencies, disasters, and catastrophes [28]. However, another line of thinking challenges the previous classification that only focuses on the magnitude or level of destruction and suggests the psychological impact of an event on individuals and societies as the right classification [24, 26, 21]. In this sense, disasters and catastrophes can be perceived as emergencies, but with a large scale of magnitude or negative impact on people and/or properties.

Since the dawn of humanity, people dealt with emergencies using whatever tools and methods available, but starting in the twentieth century a more systematic approach did organize the scattered efforts of mankind leading to the establishment of emergency management as a science, art, and a discipline of research [7]. According to Haddow et al. [15], contemporary emergency management can be defined as the field that is specialized in dealing with and avoiding emergencies by developing and improving policies, procedures, contingency plans, applications, and strategies that contribute in creating safer and sustainable society.

Several technologies can be considered as solutions for emergency management over mobile devices. One of these technologies, according to the Swedish Company of Ericsson, is Multimedia Broadcast Multicast Services (MBMS) which can be ex- 
ploited to disseminate emergency messages with rich multi-media content, such as voice instructions or interactive maps, to a specific geographic area [17]. Other technologies, including Enhanced Messaging Service (EMS) and Multimedia Messaging Service (MMS), can also support the transmission of digital images or audio alerts over mobile telecommunications networks [14]. Nonetheless, these technologies theoretically have the ability to work only on new types of mobile phone devices, such as smartphones, but cannot be utilized to deliver rich-content emergency-related information to traditional mobile devices [16]. This fact unfortunately restricts the use of these technologies as a feasible solution in emergency management, specifically in developing countries where a high percentage of old mobile devices are largely still in use [22].

Other technologies do exist and can satisfy most of the requirements needed for emergency management on traditional mobile devices and over fairly-old generations of wireless telecommunications networks like the $3 \mathrm{G}$. According to a report by the European Telecommunications Standards Institute in 2006, Short Messaging Service (SMS) and Cell Broadcast Service (CBS) technologies can be used for emergency management, and were supported by the majority of mobile devices at that time [31]. Smartphones and new mobile devices also support SMS and CBS [13] making these two existing technologies an ideal option that maps the status and need of developing countries. According to the European Telecommunications Standards Institute [31], SMS and CBS can fulfill most necessities required for warning frameworks in crises. These two technologies share two criteria: to start with, they both fulfill essential requirements for emergency management by means of mobile through knowing the location of the mobile with a certain timeline; second the two technologies can offer help to the overwhelming larger part of presently utilized mobiles, including obsolete ones; something that the technology, right now, does not offer [6].

\subsection{Short message service (SMS)}

SMS is a notable and acknowledged method of correspondence. It is fit for transmitting a constrained size of binary or text messages to at least one party. SMS offers a virtual assurance for message conveyance to its recipient [31]. If there should arise an occurrence of an inaccessible network or short breakdown, the message is put away in the Short Message Service Center (SMSC) compartment and later delivered when the network or destination winds up accessible. Additionally, the message is delivered if the mobile handset is busy in with any voice and/or data activity. SMS messages don't expend much bandwidth, even though the system assets may wind up noticeably over-burden if a massive number of SMS messages and additionally telephone calls have been started all the while. Furthermore, postponement can happen and may bring about delivery failure, especially during times of emergencies and disasters.

SMS does not give any geo-location data independent by itself. such data can be gotten from different assets in the telecommunications network (e.g. the Cell-ID). SMS can possibly be utilized for location-based mobile phone emergency services, 
Paper-The Viability Of Mobile Services (SMS And Cell Broadcast) In Emergency Management...

where mass SMS messages can be coordinated to versatile numbers when they have been recognized to exist in assigned region(s) [19].

\subsection{Cell broadcasting service (CBS)}

Cell Broadcasting Service is one provided by mobile network provider where identical text messages are broadcast arbitrarily to every single mobile in a specific geographic region. The messages can be broadcast to one cell tower or all cells in a transporter arrange [31]. Contrary to an SMS, the nature of CBS does not allow twoway communication which clarifies why this technology has not been broadly sent for business applications [33]. The cell broadcasting range has the limit of around 64000 distinctive, consistent channels, with the possibility to utilize each channel for an alternate kind of service messaging. Agreed it is a broadcasting service, the CBS does not require the recognizable proof or the presence of any mobile number. Like the radio service, where the common just the initialized radio frequency (allocated to a recurrence), would receive the broadcast. Hence, the handset must be changed on to a exact CBS channel to begin accepting messages [16].

Table1 provides a comparison between the characteristics of the two most feasible technologies that can be utilized for emergency services via mobile phones; SMS and CBS. The characteristics were adapted from The GSMA- Disaster Response [32].

\section{The Current State of Emergency Management Mobile Solution in a Number of Developing Countries}

The implementation of mobile phone in emergency management basically depends on infrastructure of mobile telecommunication companies. Aloudat et al. [5] argues that these companies should be supported by governments through contractual agreements. The nature of the agreements, albeit unique to every company, will discuss compensation mechanisms, techniques devoted for presenting services, and legislation. Table 2, shows number of developing countries that have already deployed its emergency management mobile solutions, or are planning to deploy the solutions, using SMS, CBS, or both. The table also illustrates the participation of the mobile service provider; whether it is obligatory or voluntary, and the compensation mechanism from the government for using the service provider's network and infrastructure. 
Paper-The Viability Of Mobile Services (SMS And Cell Broadcast) In Emergency Management...

Table 1. SMS and CBS, a comparison

\begin{tabular}{|c|c|c|}
\hline Characteristic & Short Message Service & Cell Broadcast Service \\
\hline \multicolumn{3}{|c|}{ Services } \\
\hline Transmission Type & Message sent point to point & Message sent point to area \\
\hline $\begin{array}{l}\text { Message dependency } \\
\text { on mobile number }\end{array}$ & $\begin{array}{l}\text { yes- requires the input of specific phone } \\
\text { numbers and database maintenance. }\end{array}$ & $\begin{array}{l}\text { NO - does not require the input of spe- } \\
\text { cific phone numbers. }\end{array}$ \\
\hline $\begin{array}{l}\text { Message Dependency } \\
\text { on Location }\end{array}$ & $\begin{array}{l}\text { NO - message received independent of } \\
\text { location, only registered numbers noti- } \\
\text { fied. }\end{array}$ & $\begin{array}{l}\text { YES - all mobile stations within a de- } \\
\text { fined geographical area notified }\end{array}$ \\
\hline $\begin{array}{l}\text { Two-way Communi- } \\
\text { cation }\end{array}$ & $\begin{array}{l}\text { Yes - users can both receive and respond } \\
\text { directly to the sender }\end{array}$ & $\begin{array}{l}\text { Not direct response - users cannot reply } \\
\text { directly but can respond through num- } \\
\text { bers or URLs included in message. }\end{array}$ \\
\hline $\begin{array}{l}\text { Sensitivity to Disaster } \\
\text { network conditions }\end{array}$ & $\begin{array}{l}\text { Will often succeed in poor radio condi- } \\
\text { tions, due to air occupancy for a short } \\
\text { message of only a few tens of ms. Uses } \\
\text { signaling radio channels, which can be } \\
\text { subject to congestion in a disaster. Huge } \\
\text { volumes can be subject to delays if sent } \\
\text { during a disaster. }\end{array}$ & $\begin{array}{l}\text { Broadcasts are sent on dedicated chan- } \\
\text { nels therefore congestion unlikely, } \\
\text { though delays to message delivery may } \\
\text { occur in areas of poor coverage. }\end{array}$ \\
\hline Repetition & No repetition rate & $\begin{array}{l}\text { Messages can be repeatedly broadcast } \\
\text { periodically by the GSM BSC/BTS } \\
\text { within the range } 2 \text { s to } 32 \text { minutes. }\end{array}$ \\
\hline $\begin{array}{l}\text { Security and message } \\
\text { integrity }\end{array}$ & $\begin{array}{l}\text { Poor - no indication that a message is } \\
\text { generated by a legitimate authority, and } \\
\text { message can be "spoofed" from other } \\
\text { phones. }\end{array}$ & $\begin{array}{l}\text { Good - safeguards prevent an outsider } \\
\text { from generating a cell broadcast mes- } \\
\text { sage, therefore false or spam alerts are } \\
\text { unlikely. }\end{array}$ \\
\hline \multicolumn{3}{|c|}{ Message } \\
\hline Message Size & $\begin{array}{l}140160 \text { characters. Maximum of } 5 \\
\text { messages can be concatenated }\end{array}$ & $\begin{array}{l}93 \text { characters. Maximum of } 15 \text { Concate- } \\
\text { nated Pages. }\end{array}$ \\
\hline Message Type & $\begin{array}{l}\text { Static messages will be sent only to all } \\
\text { registered numbers. }\end{array}$ & $\begin{array}{l}\text { Custom messages can be sent to differ- } \\
\text { ent areas to reflect different alert status } \\
\text { or hazards. }\end{array}$ \\
\hline $\begin{array}{l}\text { Message Display } \\
\text { Notification }\end{array}$ & Display can be controlled by user & $\begin{array}{l}\text { For subscribed handsets messages can } \\
\text { be automatically pushed to the screen } \\
\text { and a distinct alert sounded }\end{array}$ \\
\hline Handset Compatibility & Compatible on all handsets. & $\begin{array}{l}\text { Compatible on most handsets but may } \\
\text { require manual configuration or software } \\
\text { client on handset. Presentation may } \\
\text { differ across handsets. }\end{array}$ \\
\hline Reception & $\begin{array}{l}\text { Message received once the mobile is } \\
\text { switched on. }\end{array}$ & $\begin{array}{l}\text { No message received if broadcast is sent } \\
\text { whilst mobile is switched off. However, } \\
\text { if updates to the cell broadcast are sent, } \\
\text { they will be received when mobile is } \\
\text { switched on. }\end{array}$ \\
\hline Delivery Confirmation & $\begin{array}{l}\text { Yes - sender can request delivery con- } \\
\text { firmation }\end{array}$ & No - no confirmation of delivery. \\
\hline Language selection & No. Identical to all receivers & $\begin{array}{l}\text { Yes. Messages can be broadcasted in } \\
\text { subscriber's preferred language }\end{array}$ \\
\hline
\end{tabular}


Paper-The Viability Of Mobile Services (SMS And Cell Broadcast) In Emergency Management...

Table 2. Developing Countries with a Deployed Emergency Management Mobile Solution

\begin{tabular}{|l|l|l|l|l|}
\hline \multicolumn{1}{|c|}{ Country } & $\begin{array}{l}\text { Nature of partic- } \\
\text { ipation }\end{array}$ & \multicolumn{1}{|c|}{ Type of Agreement } & $\begin{array}{c}\text { Government finan- } \\
\text { cial compensation }\end{array}$ & \multicolumn{1}{|c|}{ Technology } \\
\hline Bangladesh $^{1}$ & Obligatory & Contractual agreement & No compensation & SMS and CBS \\
\hline India $^{2}$ & Voluntary & Oral agreement & No compensation & SMS and CBS \\
\hline Lebanon $^{3}$ & Unknown & \multicolumn{2}{|l}{} & SMS and CBS \\
\hline Maldives $^{4}$ & Obligatory & $\begin{array}{l}\text { Legislation and contractual } \\
\text { agreement }\end{array}$ & No compensation & CBS \\
\hline Nigeria $^{5}$ & Voluntary & Memorandum of Understanding & No compensation & CBS and SMS \\
\hline Samoa $^{6}$ & Voluntary & Regulatory framework & No compensation & CBS and SMS \\
\hline Sri Lanka & Obligatory & Legislation & No compensation & CBS and SMS \\
\hline
\end{tabular}

Sources: 1[1], 2[9], 3[30], 4[33], 5[19], 6[20], 7[10].

\section{$5 \quad$ Research Methodology}

A Qualitative approach in the form of semi-structured interviews were applied to obtain points of view and opinions regarding the interest of this research. Using interviews is highly recommended because of the exploratory nature of this research that looks into a fairly new area of research; which is to understand the viability of mobile devices as a convenient and economic alternative to emergency management solutions in developing countries. Furthermore The semi-structured approach allowed the researcher to ask follow-up questions for clarification as the interview progressed.

Eight interviews were conducted with high-profile experts from Jordan. It is important to note this number of interviews are quite adequate since the focus is to obtain in-depth insights from individuals who are professionally involved in the planning and developing of country-wide strategies. The interviewees were carefully selected from the fields of national security, emergency management, e-government, and mobile telecommunications. The ultimate goal was to construct a comprehensive perspective that not only stands upon understanding the value of mobile devices for emergency management, but also the requirements and directions of these devices in national emergency management solutions in developing countries.

An interview protocol containing a set of questions that are related to the subject of matter was designed to guide each interview. Additional questions were included to probe and expand on specific areas of interest, once raised. All interviews were carried out face-to-face, between December 4th, 2016 and March 2nd, 2017. Each interview lasted between 45 to 85 minutes. Fortunately, all interviews were recorded upon explicit consent and approval from the interviewees. Each interview was transcribed and the generated text was audited twice to guarantee a complete match with its original audio file.

Following the recommendations of Miles and Huberman [18], the content analysis technique was performed to analyze the interviews. In this method, the open-coding technique were automatically identified by the Leximancer software to determine and extract basic concepts from each interview [2]. Leximancer is a software tool designed for analyzing natural-language text data. Leximancer was used in coding 
would improve the overall reliability in the content analysis since potential errors in coding, due to inaccurate human judgement and fatigue, can be largely avoided. Later, related concepts and all supporting statements were carefully clustered to create a specific theme. Finally, the themes were reported, discussed, and presented as the findings of this research. The personal details of the participants were removed to allow for anonymity in responses but wherever possible company and organisational names remained. However, as an acknowledgment to all of the interviewees' valuable responses, a summary of the eight interviewees and their background is presented in Table 3.

Table 3. List of Experts Interviewed

\begin{tabular}{|c|c|c|c|c|}
\hline No & $\begin{array}{l}\text { Interviewee } \\
\text { Pseudonym }\end{array}$ & Description & Date & Duration \\
\hline 1 & Expert A & $\begin{array}{l}\text { Holds a high degree in telecommunications engineer- } \\
\text { ing from the University of Manchester, UK, with } \\
\text { more than fifteen years of practical experience in the } \\
\text { field of ICT in the European Union. Works with a } \\
\text { leading mobile service provider in Jordan. }\end{array}$ & $\begin{array}{l}\text { December } 4^{\text {th }} \\
\quad 2016\end{array}$ & 45 minutes \\
\hline 2 & Expert B & $\begin{array}{l}\text { A well-known consultant in security strategies. Holds } \\
\text { a Ph.D. in National Security Management from } \\
\text { Colorado Technical University, USA. Works with the } \\
\text { Ministry of Planning \& International Cooperation, } \\
\text { Jordan. }\end{array}$ & $\begin{array}{l}\text { December } 12^{\text {th }}, \\
\quad 2016\end{array}$ & 60 minutes \\
\hline 3 & Expert C & $\begin{array}{l}\text { Professional and Researcher in Information Systems } \\
\text { and Technologies. Hold a Ph.D. in Geographic Infor- } \\
\text { mation Systems form Newcastle University, UK. } \\
\text { Works with the Royal Jordanian Geographic Cen- } \\
\text { ter (RJGC). }\end{array}$ & $\begin{array}{l}\text { December } 16^{\text {th }} \text {, } \\
\quad 2016\end{array}$ & 50 minutes \\
\hline 4 & UN Expert & $\begin{array}{l}\text { Expert in early warning systems and technologies } \\
\text { related to floods. Works with the United Nations } \\
\text { Development Program (UNDP) in Jordan. }\end{array}$ & $\begin{array}{c}\text { January } 8^{\text {th }}, \\
2017\end{array}$ & 50 minutes \\
\hline 5 & Expert D & $\begin{array}{l}\text { Responsible of developing policies and programs } \\
\text { concerning the use of Information and Communica- } \\
\text { tions Technology (ICT) for public safety. Works with } \\
\text { the National Emergency and Crisis Management Cen- } \\
\text { ter in Jordan. }\end{array}$ & $\begin{array}{c}\text { January } 22^{\text {nd }}, \\
2017\end{array}$ & 60 minutes \\
\hline 6 & $\begin{array}{c}\text { Government } \\
\text { Representative }\end{array}$ & $\begin{array}{l}\text { High-ranked government official with more than } \\
\text { twenty years of experience in technology and elec- } \\
\text { tronic government services. }\end{array}$ & $\begin{array}{l}\text { February } 13^{\text {th }} \\
\quad 2017\end{array}$ & 85 minutes \\
\hline 7 & $\begin{array}{l}\text { Rescue Center } \\
\text { Manager }\end{array}$ & Director of a civil defense rescue center in Jordan. & $\begin{array}{l}\text { February } 26^{\text {th }} \\
\quad 2017\end{array}$ & 55 minutes \\
\hline 8 & $\begin{array}{l}\text { Rescue Team } \\
\text { Officer }\end{array}$ & $\begin{array}{l}\text { Field officer in search and rescue, civil defense, } \\
\text { Jordan. }\end{array}$ & $\operatorname{March} 2^{\text {nd }}, 2017$ & 48 minutes \\
\hline
\end{tabular}

\section{Findings and Discussion}

The main themes found by the content analysis conducted by the researchers in addition to the core themes in the textual data from the interviews were automatically identified by the Leximancer tool. Leximancer was capable of determining the core 
themes in the textual data, which helped to ensure that they matched the main themes found by the content analysis. The themes, identify by Leximancer and their related concepts, in addition to the themes identified by the iterative content analysis approach [18], are fully explored in the discussion presented in this section.

\subsection{The need for an adaptive mobile emergency solution to changing technologies}

If a decision is made to utilize an existing solution in a relatively new domain; i.e., mobile devices for emergency management in a developing country, the solution must work with whatever technologies that will emerge in the future, but still be compatible with the existing ones. The solution should not be restricted to work with only one specific technology. Depending on a sole technology could be exceedingly risky, especially when it concerns life-saving and emergency conditions. Expert $\mathrm{C}$ confirmed: "even when we talk about the context of a developing country we should look for a technology that is able to develop over time, thus satisfying the needs for it now, and for at least ten years ahead.

Focusing only on one mobile technology, even if it exits and can be used, is dangerous as this technology can quickly become obsolete". Expert C added: "I would like to give an example about SMS. In spite of the popularity of SMS, we have to keep in mind that it relies on what is called circuit-switched and, therefore, it cannot scale-up very well when a decision is made to send a message to many people in case of an emergency". The expert continued: "if we want an effective national plan for emergency management that relies on mobile devices, and in order to have a system that warns people over their mobile devices, then we should first critically evaluate all existing technologies". Expert C warned from those who walked toward a dead end in their thinking about an existing technology as an emergency management tool, that which cannot be used in the future and cannot adapt to the continuous changes in technologies, needs, and infrastructures. Expert $\mathrm{C}$ ended: "Any investment in this type of technology is practically a waste of time". Expert B did confirm: "Applying SMS in a wide-range emergency warning system is difficult, and will remain difficult". He continued: "Governments need a system that is able to be developed in an ascending manner. It should be able to send from ten messages up to a million messages in a matter of seconds. Development of such system is quite a major concern when current mobile technologies are used".

Another point of importance is that there is a need to use a technology that can endures heavy impacts in emergencies, and at the same time be flexible enough in where at least part of it still functions in case its major parts break down. Expert A, pointed to the technical issues that should be resolved in case mobile services were used within extreme dangers, earthquakes for example, since earthquakes affect telecommunications towers and restricts the delivery of messages to affected people. Expert D concurred; "technical issues should be taken into consideration when proposing a national emergency service that relies on using mobile. There should be a clarification that in case of large-scale emergency if all cell towers were destroyed then government emergency messages would be affected. Expert D added: "Some 
countries have highly flexible systems, in South Korea, for example, telecommunications companies along with government authorities have flexible networks that can function again within only 24 hours after a tornado".

\subsection{Ensuring social equality under the proposed mobile emergency solutions}

While there is a need to find solutions that have the ability to develop over time, there is also a need for a solution that can balance between old mobile devices and new ones. Expert A explained: "The selected technology should offer justice for all, it should rely on the least- and not the most- common denominator; the oldest and not the newest mobile device versions. This is quite true in a country where many people still own old mobile phones. One should not loose life because he or she owns an old mobile, and smartphone owners should not be more fortuned than others in this context".

\subsection{Considering the limitations of existing technologies in future mobile emergency solutions}

The UN Expert admired the technology of CBS, but stressed the fact that they are not fully supported over all mobile telecommunications networks or even vendors of mobile devices. Expert A, drew the attention to a technical point in regard to SMS and CBS. In case of SMS, one message is sent at the time to one or multiple recipients, but the message can be sent from any mobile carrier in the country. On the other hand, a carrier disseminates one CBS message over a dedicated mobile phone CBS channel to all mobile devices residing in a specific geographic area, but the drawback here is that only the subscribers with that carrier would receive the message. People who are on other networks would not receive it.

Expert D also expressed his fears regarding the use of cell broadcast service technologies; "We excluded the comprehensive use of cell broadcast service simply because it covers a wide area, while we need a more precise technology. A good practice in emergency management includes notifying only people at risk. For example, sending warnings via CBS to a threatened area means that warnings may reach unintended individuals from adjacent areas due to the large geographic area the mobile cell towers can cover, hence resulting in spreading a needless public panic".

The representative of the e-government pointed out that the wide-range coverage of cell broadcast has a technical limitation: "a cell covered by broadcast tower may have a range up to 18 kilometers in some rural areas". He illustrated a scenario where there is a need to notify people who are located with only one kilometer range of the cell tower center, but in the case of CBS people who are very far from the intended area will also be notified; "notifying people in unaffected areas will have adverse effects, and will let people distrust any further governmental warnings".

Any technology has limitations. The e-government representative noted: "Whatever government does, it cannot achieve a comprehensive coverage to all citizens, as their mobiles might be simply switched off, we should be practical". Expert D stated: "From our experience we got to know factors affecting evacuation of people from 
threatened areas. In the context of a warning system that is based on SMS, for example, one of the major limitations is the shortness of the message which cannot include the whole safety information. In an emergency operations, the important thing is to draw people's attention first, and then to make them do something like getting more information about places of shelters. This would be extremely difficult to manage through SMS technology".

Third limitation was described by the general safety expert who said: "Some tremendous disasters impose challenges that can't be overcome by geography-based warning solutions, as these disasters may be spreading too quickly, or we can't predict them precisely. This necessitates a governmental accurate study to a certain limited number of disasters that can be effectively managed through LBS where potentials of (LBS) should be evaluated"

United nation's expert commented: "We should be realistic from the technical point of view when building a system. Public's expectations should be reasonable as information provided by warning system is limited in its precision and accuracy".

\subsection{Public education and awareness before any mobile emergency solution}

Concerns raised about the need to make the public be informed about any technology if a decision is made to utilize it in emergency management. Expert B pointed out to an important fact that the majority of mobile phone owners do not use CBS or even know this technology exists which constitutes a real awareness issue if a decision is made to rely, for example, on this technology in emergencies.

Expert A also confirmed the fact that the majority of people are unaware of the existence of CBS, which creates the need for awareness campaigns and public preparation. Expert A clarified: "This necessitates spreading awareness through public campaigns since it is not enough for people to get a CBS message without knowing from where it came, or what it actually meant".

The UN expert suggested a technique to overcome the issue of managing people who may not pay attention to warning messages received: "The technique is simple. You can send a warning message while simultaneously exploit other channels like sirens if exist. This will make people switch on to radio, TV, or start to pay attention to messages received over their mobile devices". He added: "These operations are complicated as you have to educate people on what and what not to do over each incident. Sometimes you have to educate people about the appropriate way for evacuation which cannot be fully achieved by mobile devices alone".

According to the Rescue Team Officer, conducting trials and experiments by government with people before applying the national solution is very crucial: "there should be regular training and trails to avoid any possible negative effects on public, such as false alarms or panic, which may lead to the ultimate failure of these solutions".

Governments have to prepare people on how to face threats associated with emergencies, whether these emergencies are natural or manmade. This preparation has the advantage of building strong societies that are able to endure and adapt with extreme 
events. Strong societies help in achieving the objectives of national warning systems, including those based on mobile emergency services.

Expert A noted that if panic spreads, social aspects should not be ignored. He suggested using social media to enable communication between people and government. He said: "We might have individuals who start acting as volunteers spreading messages on Facebook or twitter to help people communicate vital information relevant to disasters, in addition to provide government authorities with real information about the situation in case the disaster persists for some time".

The Rescue Center Manager stated that there would be communication problems among some citizens as they have different cultural and educational levels. He added: "Education is the key to solve many problems facing waning systems. We need to be mentally prepared to disasters; this can be achieved through educating children, and societies about how to get prepared to all disasters". Part of the education should be directed towards what people should do when they receive warning messages via their mobiles. The UN Expert said: "Challenges here are rather cultural than technical, the best solution is to prepare people on how to respond correctly when they receive warning messages. Therefore, an emergency warning system that is based on mobile phones needs to be applied along with an educational program. People have to know that they will receive warning messages from time to time. Theoretically speaking, we can prepare the overwhelming majority of citizens. Few categories of society will still need further help from government or from charities and non-government organizations". The Expert gave two examples of these categories: An old lady who has difficulty in hearing and receives a mobile message about gas leakage while sleeping, and an old gentleman who is illiterate but receives a warning message about an impending emergency.

Public education and awareness are indeed major issues for governments and are actually on the agendas of many countries. The Government Representative confirmed: "Governments plan to spread their services along with nation-wide awareness campaigns. We are not only targeting public, but also different government agencies and all relevant parties, such as school administrators who have hundreds of kids to take care of. Awareness becomes a necessity where we have mass of people in specific places, such as universities and companies".

\subsection{Avoiding designing a solution for a specific type of emergency}

Mobile emergency solutions should not be designed to only support specific type of emergencies, but they should support them all. The Rescuer Center Manager confirmed this by stating: "If governments and emergency management agencies did not design national warning systems in a manner that covers all types of disasters and emergencies, then there would be a loss in lives. By law we will be responsible for it". 


\subsection{Guidelines with the content of the emergency message}

The content of a warning message should be clear and simple. A point the Government representative clearly identified is: "we should be realistic about peoples' understanding of the warning message, as the message can be simply misunderstood". The UN Expert confirmed by stating: "Information sent to the public should be accurate and effective upon delivery, and well organized from the early beginning. There should be clear instructions about what to do in case there is a problem in communications or in people's understanding of the message. In addition, problems should be solved next time so as people would not lose confidence in government warning systems. People should know that any message from the warning system is urgent and should not be ignored, that is why messages should be professional and adequate".

Expert D, from the National Emergency and Crisis Management Center in Jordan, argued that there should be strict protocols for spreading information relevant to emergencies and should be accurately followed; similar to what is prevalent in any other media that educates people in case of an emergency. He stated: "Currently we have specific steps in notifying media about an emergency. These steps are strictly controlled, where only assigned government officers have the right to notify media. Those officers are trained and have a license to spread information to media".

\subsection{Use of government mobile services in case of severe emergencies only}

Mobile emergency services should be used only in case of a large-scale emergency. The Rescue Center Manager contended: "It does not make sense to wake up millions of people in Amman [the Capital of Jordan] to tell them there will be a snow storm unless it is unprecedented in scale or in its unexpected magnitude. The warning system over mobile devices should not be used for casual things as this will only lead to unnecessary panic. In addition, it is preferred to use the warning system in very certain cases when it is the only tool to spread life-saving information quickly". The interviewee suggested that other channels, like radio and TV, should be used to broadcast information about simple incidents while leaving any suggested mobilebased system to manage severe emergencies only. He concluded: "We do not want to end up with a system that people complain from its messages in each and every incident happened around them".

Indeed, too many warning messages may have unwanted adverse effect on people's evaluation of mobile emergency services, and the benefits of these services will be undermined specifically in major events. The Rescue Center Manager agreed: "One of the governments put specific altering censors in a chemical plant, where sirens were triggered whenever minor leaks happened which introduced potential risk to neighboring areas. After couple of months, people got bored and cut the wires of the alerting system because they did not want to know about a potential disaster". The interviewee continued: "such services should be wisely managed so as to keep people's trust in the government and its emergency systems". Expert B also concurred: "What we actually need is less warning messages, sent to the intended people only, and which their content is carefully formulated". 
6.8 Build a partnership and shared responsibility between government and non-governmental organizations

Building a national approach for emergency system based on mobile devices needs the participation of governments, non-profit, and non-government organizations. The UN Expert argued: "we need a comprehensive participation from all government agencies during emergencies. After all, government agencies are the main entities which are responsible for emergency management. When a government notifies people that they should evacuate, then it should present a clear explanation of the best way to do that. However, not everyone can move by himself. In this context, we do not want to spread panic which would be expected, as some community members need more assistance in following instructions. Non-government organizations can do the role of help here".

Expert A also stated the importance of sharing responsibility between government and non-government entities: "All emergency management systems are in fact a partnership between governmental and non-government organizations to convey warning messages effectively. We still need groups of national volunteers or social service organizations to help rescuing operations such as evacuation, managing shelters, or guiding people to safe places". The Government Representative concurred: "It is very important to consult a number of groups about this mobile solution to be used in the future for managing emergency. We have government agencies, voluntary groups, and non-government organizations, all of which have different plans and strategies during emergencies. To ensure acceptance and sustainability of the to be used emergency management solution, we have to consult these groups and get their participation, otherwise the acceptance of the system will be low".

\subsection{Toward a collaboration between government and private telecommu- nications providers}

Realizing the fact that deploying mobile emergency solutions depends on using the infrastructures of the private telecommunications companies and effective collaboration between government and these companies becomes a necessity in achieving the success of these services. The Government Representative suggested that there should be also good collaboration among these companies themselves [i.e., telecommunication companies], which should be in harmony with the trends of the government to manage its national emergency management. He stated: "we cannot talk about a trend in future emergency services without considering a real partnership between government and telecommunications companies, and between these companies".

\subsection{Financial compensations for telecommunications companies within emergency management solutions}

The participation of mobile phone companies in national emergency systems is inevitable. As a result, a compensation mechanism from the government to these companies should be. Expert D contended: "everything during a mobile emergency solu- 
tion needs support from the telecommunications companies. They provide us with data and they are the only entity capable of providing necessary infrastructure of networks, cell towers, communication tools, as well as data about people who are located in a designated geographic area. This data is vital in sending government messages to people". The Expert continued "the cost factor is a major limitation for their participation in a national mobile emergency solution as these solutions may constitute a heavy burden on their infrastructure. Telecommunication companies will also need more investment to scale up infrastructure in order to enable government to deploy its emergency services when needed. A financial schema for compensating these companies should exit in any future solution".

\subsection{Opt-in and opt-out system design issues}

In regard to the opt in/opt out design aspects, a number of interviewees agreed that every person should receive the warning message without having the opt-in option built into the location-based mobile phone warning SMS and CBS. In addition, most viewpoints concurred that the SMS and CBS services should not have an opt-out option. In other words, each individual is obliged to receive the warning notification if they are located in a defined emergency area. The role of the government is to provide societal securitisation to protect citizens and residents from harm. As the Rescue Center Manager pointed out, "if you make it an opt-in system does that mean you let all those who opt-out just die? There is something inherently unethical about such a systems design. Expert B emphasises that during an emergency there is no opt-out, "it is compulsory to receive the warning message".

\section{Acknowledgement of Presence of Some Limitations in Mobile Service in Emergency Management}

Like any technology, Mobile Service in Emergency Management has some limitations.

- However good the mobile service, it cannot achieve a comprehensive coverage to all citizens. Mobiles might be simply switched off, phones might be on 'silent' mode, or just out of reach. Therefore, mobile emergency management system must be in combination with another type of warning system. Some experts suggest a technique of sending messages simultaneously whilst releasing sirens. This will make people switch on radios or T.V.s, or pay attention to service providers' instructions.

- Some people may misunderstand warning messages.

- Messages may not contain the whole information due length restrictions especially with SMS technology.

- Some disasters impose tremendous challenges that cannot be overcome by mobile warning solutions, as these disasters may be spreading too quickly, or have a more elusive predictability. 
- Information provided by warning system is limited in its precision and accuracy, as such, the public's expectations should be reasonable.

\section{Conclusion and Recommendations}

In this study, a discussion was made about the idea of using mobile phone services for emergency management in developing countries, taking into account the economic barriers for investing in dedicated emergency management solutions in such countries. Related definitions were first presented in regard to the concepts of emergency and emergency management, and an overview was provided about the main mobile phone technologies that exist today which theoretically can be utilized in the domain of emergency management.

The study then presented the findings of the qualitative content analysis of eight semi-structured interviews that were carried out with experts and officials in fields related to emergency management, telecommunications, and national security. The findings did suggest the feasibility of mobile services as a convenient national emergency management solution, but a number of technical and non-technical requirements are still needed to be met before the success of such solution deployment.

The study offered vital recommendations extracted throughout interviews towards the possibility of deploying Mobile Emergency solutions in developing countries as per the following:

- The limitations of existing technologies should be carefully considered before deciding which to exploit.

- An emergency management mobile solution should be adaptable to future technologies as well as existing technologies.

- Social equality must be taken into consideration, designing a solution that can target all types of mobile devices; traditional and smartphones.

- Public education and awareness campaigns should be implemented before any solution.

- Design should support many emergency situations, and not be strictly designed to a specific type of emergency.

- The use of mobile emergency solutions only in case of a large-scale severe emergency.

- A partnership between the government and non-government organizations, and collaboration between governments and private telecommunication providers is inevitable to successfully deploying mobile emergency solutions in developing countries.

- Government financial compensation for the telecommunications companies is recommended.

In addition to the base requirements for the emergency management solutions, the requirements for the service/message itself should consider, but are not limited to the following: 
- The message generated from the solution should be clear and easy to understand

- Enable discrimination in messages sent to different categories of recipients; messages for recipients in near traumatized areas differ than those for far away ones.

- Reach all versions of mobiles in use, including old ones.

- Provide messages with supportive characteristics for those with special needs, such as a light accompanying the message for blind, or vibration accompanying the message for deaf.

- Be able to reach people who are roaming through other mobile networks.

- Be able to convey warning messages in a number of languages. This becomes very important when there are tourists from other countries.

- Have the ability to function even when communication networks are loaded.

- Offer the option of resending message in case first trial of sending failed.

- Have the ability to repeat messages as long as they are active.

- Be clear enough to ensure that recipients are sure they are the one concerned.

- have accurate in timing, offering enough time for people to take necessary precautions.

- Be precise in expectations (or in noting the expected degree of hazard).

- Be complete but brief.

Based on the findings of this study a number of research issues may need further investigation. First, there is a stressing need to investigate the social acceptance of mobile government emergency solutions in the context of developing countries. Issues related to privacy, solution design issues, perceived quality of services, and people's trust in government and its emergency mobile solutions are all possible topics of important future examination. Second, since this research has selected Jordan as the case for a developing country there is a call for other researchers to conduct comparative studies to stand upon a more comprehensive set of requirements that can influence the success or failure of mobile emergency solutions in developing countries.

\section{References}

[1] Ahmed, J. U. 2015. Role of Department of ICT in Promoting ICT Uses in Disaster Risk Reduction. Department of ICT, Ministry of Posts, Telecommunications and IT, Bangladesh Available: http://doict.portal.gov.bd/sites/default/files/files/doict.portal.gov.bd/page/ b8c2b656_1834_4e79_a8ad_ba18d396c08e/Role of Department of ICT in Promoting ICT Uses in Disaster Risk Reduction.pptx

[2] A Leximancer Company 2017, Leximancer: From Words to Meaning to Insight, viewed 28 March $2017<$ https://www.leximancer.com/>.

[3] A Leximancer Company 2017, Leximancer: From Words to Meaning to Insight, viewed 12 April $2017<$ https://www.leximancer.com/>.

[4] Aloudat, A. 2012. Privacy vs. Security in National Emergencies. IEEE Technology and Society Magazine, 31, 50 https://doi.org/10.1109/MTS.2012.2185729

[5] Aloudat, A. \& Michael, K. 2013. Towards a Conceptual Model of User Acceptance of Location-Based Emergency Services. The International Journal of Ambient Computing and Intelligence, 5, 17-34. https://doi.org/10.4018/jaci.2013040102 
Paper-The Viability Of Mobile Services (SMS And Cell Broadcast) In Emergency Management...

[6] Aloudat, A., Michael ,K., Abbas, R. \& Al-Debei, M. 2011. The Value of Government Mandated Location-Based Services in Emergencies in Australia. Journal of Information Technology Research, 4, 41-68.

[7] Canton, L. G. 2007. Emergency Management: Concepts and Strategies for Effective Programs, John Wiley \& Sons, Inc. https://doi.org/10.4018/jitr.2011100103

[8] Chin, W. H., Fan, Z. \& Haines, R. 2014. Emerging technologies and research challenges for $5 \mathrm{G}$ wireless networks. IEEE Wireless Communications, 21, 106-112.

[9] Department of Telecommunications. 2015. Standard Operating Procedure (SOP-2015) for Telecommunication Services for Responding to Disasters. Ministry of Communication \& IT, Government of India. Available: http://www.dot.gov.in/dataservices/standardoperating-procedure-sop-2015-telecommunication-services-responding-disasters https://doi.org/10.1109/MWC.2014.6812298

[10] Disaster Management Centre. 2011. Legal Framework for Disaster Management and formulating the National Disaster Management Plan (NDMP). Government of Sri Lanka. Available: http://www.dmc.gov.lk/NEW/wp-content/uploads/2015/08/Final-Draft-NDMPBody-20 Nov.2013.pdf

[11] Etikan, I., Musa, S. A. \& Alkassim, R. S. 2016. Comparison of Convenience Sampling and Purposive Sampling. American Journal of Theoretical and Applied Statistics, 5, 1-4.

[12] Gandy, S., Kern, K., Norton, J. \& Toth, A. 2014. Emergency Disaster Preparedness and Response. OLA Quarterly, 14, 1.

[13] Gojmerac, I., Preinerstorfer, A., Ruggenthaler, C., Schuster, C., Almer, A., Stocker, R. \& Heussler, V. Public warning and alert system for Austria. 3rd International Conference on Information and Communication Technologies for Disaster Management (ICT-DM), 1315 Dec. 2016 Vienna, Austria. 1-7. https://doi.org/10.7710/1093-7374.1217

[14] Gorbil, G. \& Gelenbe, E. 2013. Resilient Emergency Evacuation Using Opportunistic Communications. In: GELENBE, E. \& LENT, R. (eds.) Computer and Information Sciences III: 27th International Symposium on Computer and Information Sciences. London: Springer London. https://doi.org/10.1109/ICT-DM.2016.7857206

[15] Haddow, G., Bullock, J. \& Coppola, D. 2013. Introduction to Emergency Management, Elsevier. https://doi.org/10.1007/978-1-4471-4594-3 26

[16] Jagtman, H. M. 2010. Cell broadcast trials in The Netherlands :Using mobile phone technology for citizens' alarming. Reliability Engineering \& System Safety, 95, 18-28.

[17] Lohmar, T., Ibanez, J.-A., Zanin, A. \& Blockstrand, M. 2009. Scalable push file delivery with MBMS [Online]. Ericsson Company. Available: https://www.ericsson.com/ericsson/corpinfo/publications/review/2009 01/files/MBMS.pdf [Accessed April 12 2017]. https://doi.org/10.1016/j.ress.2009.07.005

[18] Miles, M. B. \& Huberman, A. M. 1994. Qualitative Data Analysis: An Expanded Sourcebook, Thousand Oaks, California, SAGE Publications, Inc.

[19] Modular Integrated Services Limited. 2016. Development of Best Practices in Information Infrastructure Security Management. Department Of New Media And Information Security, Nigerian Communications Commission, Government of Nigeria. Available: http://www.ncc.gov.ng/documents/710-development-of-best-practices-in-informationinfrastructure-security-management/file

[20] Office of the Regulator. 2014. Samoa National Emergency Telecommunication Plan (Netp)- Final Draft. Government of Samoa. Available: http://regulator.gov.ws/images/ publication/technical/NETP-Reviewed-Draft-2014-2.pdf

[21] Perry, R. W. 2007. What Is a Disaster? In: RODR'1GUEZ, H. A., QUARANTELLI, E. L. \& DYNES, R. (eds.) Handbook of Disaster Research. 1st ed.: Springer Science+Business Media, LLC. https://doi.org/10.1007/978-0-387-32353-4 1 
Paper-The Viability Of Mobile Services (SMS And Cell Broadcast) In Emergency Management...

[22] Poushter, J. 2016. Smartphone Ownership and Internet Usage Continues to Climb in Emerging Economies: But advanced economies still have higher rates of technology use [Online]. Pew Research Center. Available: http://www.pewglobal.org/2016/02/22/smart phone-ownership-and-internet-usage-continues-to-climb-in-emerging-economies/ [Accessed February 12 20017].

[23] Pringle, R., Michael, K. \& Michael, M. 2016. Unintended Consequences: The Paradox of Technological Potential. IEEE Potentials, 35, 7-10. https://doi.org/10.1109/MPOT. 2016.2569672

[24] Quarantelli, E. L. 1986. What Should We Study? Questions and Suggestions for Researchers About the Concept of Disasters. International Journal of Mass Emergencies and Disasters, $5,7-32$.

[25] Robinson, O. C. 2014. Sampling in Interview-Based Qualitative Research: A Theoretical and Practical Guide. Qualitative Research in Psychology, 11, 25-41. https://doi.org/10.1080/14780887.2013.801543

[26] Rosenthal, U. 1998. Future Disasters, Future Definitions. In: QUARANTELLI, E. L. (ed.) What is a Disaster? A Dozen Perspectives on the Question 1st ed. New York: Routledge.

[27] Smith, Z. W. 2014. Privacy and Security post-Snowden: surveillance law and policy in the United States and India. Intercultural Hum. Rts. L. Rev., 9, 137.

[28] Sylves, R. 2014. Disaster policy and politics: Emergency management and homeland security, CQ Press.

[29] Tanzi, T. J., Sebastien, O. \& Harivelo, F. 2014. Towards a Collaborative Approach for Disaster Management Using Radio Science Technologies. Radio Science Bulletin, 25-36.

[30] Telecommunications Regulatory Authority of Lebanon. 2012. Emergency Communications Framework: Document For Consultation. Government of Lebanon. Available: http://www.tra.gov.lb/Library/Files/Uploaded files/Draft Emergency Communications Plan Consultation - April 2012 - English.pdf

[31] The European Telecommunications Standards Institute. 2017. Digital cellular telecommunications system (Phase 2+) (GSM); Universal Mobile Telecommunications System (UMTS); LTE; Use of Data Terminal Equipment - Data Circuit terminating Equipment (DTE - DCE) interface for Short Message Service (SMS) and Cell Broadcast Service (CBS) (3GPP TS 27.005 version 14.0.0 Release 14) 650 Route des Lucioles, F-0692 Sophia Antipolis Cedex, FRANCE. Available: http://www.etsi.org/deliver/etsi_ts/127000_12 7099/127005/14.00.00_60/ts_127005v140000p.pdf

[32] The GSMA- Disaster Response, Mobile Network Public Warning Systems and the Rise of Cell-Broadcast. 2013.

[33] Tran, N. H. \& Pedler, D. 2016. The impact of extensive loss of telecommunications on general practice: A case study in rural Victoria. Australian Journal of Rural Health.

[34] Udu-gama, N. Implementing Inclusive ICTs: Mobile Cell Broadcasting for a Public Warning System in the Maldives. Second India Disaster Management Congress, 2009 New Delhi, India. 1-22.

[35] United Nations Development Program. 2016. The Human Development Report 2016 'Human Development for Everyone' [Online]. Available: http://hdr.undp.org/sites/de fault/files/2016 human development report.pdf [Accessed.[

[36] Zhang, Y., Drake, W., Xiao, Y., Olshansky, R., Johnson, L. \& Song, Y. 2016. Disaster Recovery Planning after Two Catastrophes: The 1976 Tangshan Earthquake and the 2008 Wenchuan Earthquake. International Journal of Mass Emergencies \& Disasters. 


\section{Authors}

Dr. Mahmoud Ali Al-dalahmeh (MAIS'07) holds a Doctor of Philosophy in Management Information Systems the Faculty of Informatics at the University of Wollongong, NSW, Australia('08); a Master of Applied Finance from the University Western Sydney, Sydney, NSW, Australia ('01). Al-dalahmeh has developed expertise in e-Commerce/e-Business models and approaches in both large and small business IS philosophy, management, and diffusion. He has produced 8 publications in journals and conferences on these topics. Al-dalahmeh also has teaching experience over a range of IS subject areas. He is presently an Assistant Professor in the Department of Management Information Systems, at the Facultyof Business, at the University of Jordan, and has previously been employed as an associate lecturer at the University of Wollongong, Australia. Al-dalahmeh has several publications, including in Proceedings of the Intellect base International Consortium, Journal of Information Systems Technology \& Planning - JISTP, USA, International Journal of Accounting Information Science and Leadership - IJAISL, USA, his paper "E-Commerce SelfEfficacy and Intention to Shop Online: the Empowerment of Internet marketing, Intellectbase International Consortium, Academic Conference, Atlanta, USA, awarded Academic Excellence (e-mail: m.aldalahmeh@ju.edu.jo)

Dr. Ons Al-Shamaileh is an Assistant Professor and Program Coordinator of the Information Technology Management Program at the College of Computer Information Technology, American University in the Emirates. Dr. Ons earned MSc and $\mathrm{PhD}$ degrees in E-business technology and Interactive Systems from the University of Manchester, UK. She has several publications in the areas of Human Computer Interaction and user experience. She is currently researching the factors affecting user judgments of interactive systems. Dr. Ons taught at the University of Manchester/UK and Hamdan Bin Mohammad Smart University/UAE before joining the American University in the Emirates. Besides her teaching experience, Dr. Ons is UX certified from Nielsen Norman Group NN/g and has worked as user experience consultant for various projects in the UK and UAE. (e-mail: Ons.shamaileh@aue.ae)

Dr Anas Aloudat (MIEEE'09) holds a Doctor of Philosophy in Information Systems and Technology, from the University of Wollongong, NSW, Australia ('11); a Master of Science in Computing, from the University of Technology, Sydney, NSW, Australia ('03), and a Bachelor of Science in Computing, from Mu'tah University in Karak, Jordan ('93). He is presently an Associate Professor of Information Systems and Technology in the College of Computer Information Technology, at the American University in the Emirates, and has previously been employed as an associate lecturer and research assistant at the University of Wollongong, NSW, Australia. Aloudat has published extensively in various journals, book chapters, and conference proceedings. His research interests include the social implications of the emerging technologies, government informatics, as well as research related to social media, biometrics, and location-based emergency services. Aloudat serves as an associate editor with IEEE Technology and Society Magazine and a reviewer for several international journals. He also serves as a consultant for a number of leading companies in 
Paper-The Viability Of Mobile Services (SMS And Cell Broadcast) In Emergency Management...

Jordan on IST business solutions, information management, and quality issues in higher education. (e-mail: anas.aloudat@aue.ae)

Dr Bader Yousef Obeidat is an Associat Professor of Information Systems and Information Technology at the University of Jordan. His research interests include but are not limited to 1237 Impact of knowledge management Downloaded by University Of Jordan At 00:14 03 March 2017 (PT) electronic commerce, internet banking, information systems, electronic markets and auctions. Dr Obeidat has published more than 38 papers in information systems and business. (e-mail: b.obeidat@ju.edu.jo)

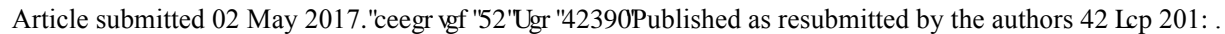

